\title{
Latex-Induced Anaphylactic Reaction in a Patient Undergoing Open Appendectomy. Case Report
}

\author{
Jean Abreu Machado, TSA ${ }^{1}$, Romilton Crozetta da Cunha ${ }^{2}$, Benhur Heleno de Oliveira ${ }^{3}$, Jane da Silva ${ }^{4}$
}

\begin{abstract}
Summary: Machado JA, Cunha RC, Oliveira BH, Silva J - Latex-Induced Anaphylactic Reaction in a Patient Undergoing Open Appendectomy. Case Report.

Background and objective: Despite the increase of latex allergy in general population, severe anaphylactic events during some surgical procedures are still rare; however, they are associated with increased morbidity and mortality. Prevention, diagnosis, treatment, and follow-up of patients affected by this event represent a challenge for anesthesiologists. The objective of this report was to describe a case of severe latexinduced anaphylactic reaction and discuss its diagnosis and treatment.
\end{abstract}

Case report: This is a 39-year-old Caucasian female patient, with a diagnostic suspicion of appendicitis, who underwent an emergency surgery under spinal anesthesia. Approximately 30 minutes after beginning the surgery, the patient developed an anaphylactic reaction with cardiorespiratory arrest, which was reversed after treatment. Possible causative agents were isolated and, posteriorly, the patient was transferred to the intensive care unit, evolving without sequelae. Latex-specific IgE-RAST (Radioallergosorbent Test) was positive. The patient was referred to an allergist for follow-up.

Conclusions: Anesthesiologists should focus on patient's history, even in urgent procedures, being aware of the limitations arising on these situations. The prognosis of anaphylaxis depends on prompt initiation of adequate treatment; diagnosis is not limited to the event occasion, but to the determination of the causative factor. Creating the means of following-up these patients, similar to other international centers, seems to be the example to be followed.

Keywords: Latex Hypersensitivity; Radioallergosorbent Test; Anesthesia, Spinal; Appendectomy; Heart Arrest.

\section{INTRODUCTION}

The first report of natural rubber-associated urticaria was described in 1927 in Germany: a case of latex allergy by type I or immediate hypersensitivity ${ }^{1}$.

Rubber allergy has became an important cause of morbidity worldwide and was recognized as an international health problem in the 1990s, when an important increase in the number of cases was seen, caused mainly by the increased use of latex gloves to prevent contact with new diseases ${ }^{1,2}$.

Received from Serviço de Anestesiologia de Tubarão - SC, Hospital Nossa Senhora da Conceição (HNSC) and Programa de Pós-Graduação em Ciências da Saúde (PPGCS), Brazil.

1. Coordinator of Serviço de Residência Médica em Anestesiologia do HNSC; MEC; Student of the PPGCS of theUniversidade do Sul de Santa Catarina (UNISUL)

2. Specialist in Ortopedia e Traumatologia from Sociedade Brasileira de Ortopedia e Traumatologia (SBOT); Orthopedist of HNSC; Student of the PPGCS of the UNISUL

3. Anesthesiologist of Serviço de Anestesiologia de Tubarão - SC

4. Professor, Physician of the PPGCS of the UNISUL

Submitted on November 16, 2010

Approved on December 13, 2010.

Correspondence to:

Dr. Jean Abreu Machado

Rua José Evaristo Fogaça, 63

Vila Moema

88705060 - Tubarão, SC, Brazil

E-mail: jean.machado@unisul.br
Rubber (polyisoprene) is extracted from the latex (sap) of Hevea brasiliensis tree, a member of the Euphorbiaceae family native of the Amazon. Natural latex is composed of cytoplasm of lactiferous cells, particles of natural rubber (cis-isoprene), and subcellular organelles that contain basic proteins; hevein, the name given to a group of latex proteins, is considered the main allergen in latex reactions, and it is present in large amounts in rubber, leading to sensitization of exposed individuals and a spectrum of allergic reactions after subsequent exposures ${ }^{3-6}$.

Allergic reaction usually occurs by direct contact of latexcontaining products, but it can also be developed by inhalation of latex particles, especially in environments with frequent use of surgical gloves, which causes a high concentration of aerosolized latex particles of cornstarch covering the inner surface of gloves as dry lubricant ${ }^{1,3}$.

The objective of the present study was to draw attention to latex allergy, as there is few case reports on type I hypersensitivity, specifically with severe anaphylaxis, which may have unfavorable outcomes. Health care professionals should be aware of this problem, whose recognition is potentially compromised during surgery ${ }^{7}$.

\section{CASE REPORT}

This is a 39-year-old Caucasian female who arrived at the emergency room with acute abdomen, that started 48 hours prior to admission, with a surgical plan of laparotomy by in- 
fraumbilical median incision. Tentative diagnosis was acute appendicitis.

During pre-anesthetic evaluation in the operating room, a few moments before the procedure, the patient reported hypertension treated with losartan, atenolol, and hydrochlorothiazide. She denied allergies or complications in surgical procedures with anesthesia in the past. On physical examination, she presented fever and abdominal pain. The patient was classified as P2 by the American Society of Anesthesiologists (ASA), and emergency surgery was performed due to the nature of the procedure.

The patient was monitored with cardioscope on $D_{\|}$derivation, non-invasive blood pressure, and pulse oximeter. After premedication with intravenous midazolam $3 \mathrm{mg}$ and fentanyl $50 \mu \mathrm{g}$, the patient underwent spinal anesthesia in $\mathrm{L}_{3}-\mathrm{L}_{4}$ space with a 27G Quincke needle, with hyperbaric $0.5 \%$ bupivacaine $15 \mathrm{mg}$ and morphine $60 \mu \mathrm{g}$. After 10 minutes, the blockade had achieved the corresponding level of the $T_{5}$ dermatome. The patient received intravenous cefazolin $1 \mathrm{~g}$ before the procedure. Approximately 30 minutes after the beginning of the surgery, the patient developed dyspnea, bronchospasm, bradycardia, hypotension, and psychomotor agitation that did not respond adequately to ephedrine, aerosolized $\beta$-agonist, and fluid therapy with crystalloids. Due to patient's worsened condition, we decided to perform tracheal intubation with rapid sequence and mechanical ventilation. She developed cardiorespiratory arrest with pulseless electrical activity, and resuscitation maneuvers were instituted and intravenous epinephrine was administered. Her cardiac rhythm returned in sinus tachycardia, which was followed by another cardiac arrest that was reversed. Due to the hypothesis of anaphylactic shock, any agent potentially responsible, drugs and latex, among them, were removed. Gloves, infusion sets, and anesthesia circuit were switched to latex-free material. Other medications used were promethazine, hydrocortisone, ranitidine, and continuous infusion of epinephrine. In addition to the previously mentioned monitoring, invasive blood pressure, central venous pressure, and capnography were performed.

After surgery, the patient was transferred to the Intensive Care Unit (ICU), sedated and on mechanical ventilation, with stable vital signs. She was extubated on the first postoperative day. On the third day, still in ICU, she developed acute pulmonary edema and had to be returned to mechanical ventilation.

Patient was discharged from the ICU one week after the initial diagnosis of latex allergy without sequelae. Blood sample was collected and latex-specific IgE-RAST (Radioallergosorbent Test) level was over $100 \mathrm{KU} / \mathrm{L}$ (class 5 - above 50 $\mathrm{KU} / \mathrm{L}$, considered "extremely high").

The new questions asked to the patient in the postoperative period confirmed the suspicion of latex allergy, with the presence of reaction to rubber gloves, allergy to banana, avocado, and kiwi. She said she worked in the support area of the operating room and had to wear silicon gloves. When asked why she did not report this fact to the anesthesiologist, she answered that she did not believe it could affect the procedure.
The patient was referred to an allergist for follow-up and differential diagnosis with a complete list of medications and substances used during the anesthesia/surgery. One of the late findings was worsening of symptoms when in daily contact with latex, especially bronchospasm and urticaria.

In addition to verbal explanations, she was given a report of her hospitalization with details of what had happened and a medical information card about her clinical condition to be carried along with her documents, in case of an emergency.

\section{DISCUSSION}

In the case presented here, as it was an emergency surgery, the anamnesis was performed by the anesthesiologist on his first contact with the patient in the operating room. This is not the ideal environment for a clinical investigation. The anesthesiologist should to be as clear as possible when questioning patients about their health. Factors, such as stress, pain, or communication difficulties may hide relevant factors. Data from admission are often enough to provide information about the patient's occupation, therefore alerting the physician to a possible risk group.

The clinical manifestations of latex exposure range from contact dermatitis, which is not mediated by the immune system, to late hypersensitivity reaction type IV mediated by $T$ cells and immediate hypersensitivity reaction type I, also known as anaphylactic or $\lg \mathrm{E}$-mediated reaction ${ }^{3}$.

Regarding the degree of severity, type I reactions can be divided into: I) cutaneous-mucous signs; II) moderate multivisceral signs; III) life-threatening with mono- or multi-visceral signs; IV) cardiorespiratory arrest; V) death due to inadequate response to cardiorespiratory resuscitation maneuvers ${ }^{8}$.

The patient described here, according to the classification of severity, was initially stage III, but she rapidly evolved to stage IV.

As mentioned before, peculiarities of patient who will undergo surgical procedures may mask initial cutaneous sings, which are not always present. This is the main challenge for the medical team when facing an anaphylactic reaction, in which an institution of effective treatment as soon as possible determines a reduction of morbimortality of these patients.

Using the case presented here as an example, based on the initial treatment, the first clinical suspicion was not anaphylaxis. More common complications inherent to the anesthetic technique or patient, such as extensive sympathetic blockade and bronchospasm, among others, are part of the differential diagnosis ${ }^{9}$ and are the first diagnostic option, delaying the treatment of anaphylaxis. Measures to reduce the time between the development of signs and symptoms of a complication and the adequate management should be adopted. Suspecting of an incorrect diagnosis whenever the proposed treatment is unsuccessful and remaining alert throughout the process is important for a favorable outcome.

Even with a strong suspicion of a specific etiological factor, i.e., a substance that had caused it during the anesthetic/ surgical procedure, achieving an early conclusion may induce 
treatment errors. A good example would be imputing blame to antibiotic, therefore neglecting others, such as latex, local anesthetics, and neuromuscular blockers, among others, hindering the adequate conduction of the case, as discussed below.

Epinephrine and fluid resuscitation seem to be the cornerstone in treatment of anaphylaxis, especially in grades of severity III and IV ${ }^{10}$. The following steps should be applied as soon as possible:

(a) discontinue, whenever possible, all substances suspected to be the etiological factor;

(b) maintain airway with $100 \%$ oxygen;

(c) discontinue anesthetic drugs when the event occurs during induction;

(d) administer epinephrine as soon as possible (grade IIIIV reactions);

(e) call for help;

(f) place the patient in Trendelenburg position;

(g) whenever possible, abbreviate the surgical procedure ${ }^{11}$.

Due to its $\alpha$-agonist action, epinephrine reverses vasodilation and edema, while its $\beta$-agonist action dilates airway, increases myocardial contraction, and suppresses the release of inflammatory mediators ${ }^{12}$. In adults, mild to moderate reactions usually respond to doses of 0.01-0.05 mg IV. In extreme cases, there may be a need for up to $5 \mathrm{mg}$ in one hour ${ }^{10}$. Patients who need repeated doses can benefit from continuous infusion ${ }^{13}$. In refractory cases, one might consider the administration of vasopressin ${ }^{14}$. Patients on $\beta$-blockers might required the administration of glucagon ${ }^{12}$, which might have been an alternative for the case presented here, as it was evident that the patient (who was on atenolol) showed a poor response to epinephrine and required continuous infusion of this drug.

Regarding the administration of fluids, infusion of more than $20 \mathrm{~mL} . \mathrm{kg}^{-1}$ might be necessary due to the loss from the intravascular to the interstitial space and, although both crystalloids and colloids can be used ${ }^{10}$, there is no evidence that the second is better than the first one. Considering that colloids can cause anaphylaxis, it would be prudent to avoid them ${ }^{15-17}$. Corticoids and anti-histamines have a secondary role in the treatment of anaphylaxis, helping to prevent edema, cutaneous symptoms, and recurrence of reaction up to 24 hours later ${ }^{9}$.

The etiological diagnosis of anaphylaxis is based on three distinct points that include clinical, biological, and allergic evidence ${ }^{11}$.

The clinical evidence in the case presented here was bronchospasm, hypotension, tachycardia, and cardiorespiratory arrest. Patients with clinical severity grade between II and IV should undergo further investigation ${ }^{10}$. Historical findings, when present, are important markers of latex-related complications. A history of atopy when handling rubber-containing products and food allergies, such as nuts, tomatoes, kiwi, banana, mango, avocado, among others, may show crossedreaction with latex. Furthermore, patients with a history of prolonged exposure to latex, such as children with myelomeningocele, lumbo-sacral agenesis, congenital bladder alterations, orthopedic disorders secondary to trauma, spina bifida, and multiple surgeries are also at risk ${ }^{6}$.

In general, when we take into consideration the associated symptoms of latex contact in health care professionals, we can find prevalence above $17 \%$. Approximately $70 \%$ of latex adverse events reported to the Food and Drug Administration (FDA) involve these professionals ${ }^{18,19}$.

Biological evidence of latex proteins can be accessed by non-specific serological tests, such as tryptase, and specific, such as IgE antibodies. In the case of tryptase, a natural protease found almost exclusively in mastocytes, along with histamine, are markers that reveal mastocytes activation ${ }^{20}$. The ideal moment for collection of serum tryptase is from 1 to 4 hours after the allergic reaction onset. A control sample should be measured in the preoperative period or, at least, 24 hours after the allergic reaction onset ${ }^{10}$. Increased serum levels, compared to control, is a highly sensitive indicator of anaphylactic reaction during anesthesia, but patients without increased levels with suggestive clinical presentation require investigation of a possible false negative ${ }^{21}$. If the value of serum tryptase in control is higher than the reference, investigations should take into account the possibility of mastocytosis ${ }^{22}$. Specific $\lg E$ antibodies against latex can be investigated through RAST (radioallergosorbent test) or CAP (fluoroimmunoassay - System, Phadia $A B$, Uppsala, Sweden) ${ }^{9}$. The ideal window for its determination ranges from the reaction onset up to six months later ${ }^{23,24}$.

Follow-up of patients with allergic evidence completes the investigation regarding IgE-mediated anaphylaxis. It is important to make the differential diagnosis among the substances that have no specific biological tests, since anesthetized patients rarely come into contact with only one substance or drug. The tests used for this purpose include: cutaneous tests (prick and intradermal tests); basophilic sensitization test; and direct provocation with the drug ${ }^{10}$.

Follow-up of patients is aimed at confirming the cause and to give the etiological diagnosis for future procedures. A patient who had an anaphylaxis should leave with documentation of what occurred. There is a great possibility of him/her getting in touch with the etiological factor in the future. In the case of latex, the possibility of a new contact includes a new surgical procedure, contact with rubber in an odontological or medical office, and individual protection material in his/her own house or job.

Some countries like Scandinavia, Great Britain, France, and Australia already have follow-up of cases occurring during anesthetic/surgical procedures through specific diagnostic guidelines that are aimed at improving detection practices of these cases ${ }^{10}$. Implanting the same procedure in our country would most certainly bring a significant epidemiologic contribution because the cases still are rare and under notified, although increasingly in frequency. Furthermore, the direct benefit to institutions by reducing costs with complications would be a tool for anesthesiologists, being a guide for these cases management and, finally, to all of us, contributing to the main objective of guaranteeing patient safety. 


\section{REFERÊNCIAS / REFERENCES}

1. Valls $A$, Pascual $C Y$, Caballero MT et al. Alergia al latex. Allergol Immunopathol (Madr), 2004; 32:295-305.

2. Uribe Llopis P, Barbero Del Palacio P, Alonso Cobo MT et al. Hacia un hospital sin látex. Med Segur Trab (Madr). 2008; 54:99-108.

3. Allarcon JB, Malito $M$, Linde $H$ et al. Alergia ao látex. Rev Bras Anestesiol, 2003; 53:89-96.

4. Parisi $C A$, Biló $B$, Bonifazzi $F$ et al. Alergia al látex. Arch Argent Pediatr. 2006; 104:520-529.

5. Hamilton RG. Latex allergy: Epidemiology, clinical manifestations, and diagnosis. Base de dados Up ToDate. 2010. Disponível em: <http://www.uptodate. com/online/content/topic.do?topicKey=oth_alle/4787\&selectedTitle=1\%7E5 3\&source=search_result $>$. Acessado em: 21 set. 2010.

6. Potério GMB, Braga AFA, Santos RMSF et al. Reação anafilática durante transplante renal intervivos em criança alérgica ao látex. Relato de caso. Rev Bras Anestesiol. 2009; 59:210-218.

7. Ledford DK. Perioperative anaphylaxis: Clinical manifestations, etiology, and diagnosis. . Base de dados Up ToDate. 2010. Disponível em: <http:// www.uptodate.com/online/content/topic.do?topickey=oth_alle/4787\&s electedTitle $=1 \% 7 E 53 \&$ source $=$ search_result $>$. Acesso em: 21 set. 2010 .

8. Ring J, Messmer K. Incidence and severity of anaphylactoid reactions to colloid volume substitutes. Lancet, 1977; 1:466- 469.

9. Simons FER - Anaphylaxis. J Allergy Clin Immunol, 2010; 125:S161S181.

10. Kroigaard M, Garvey LH, Gillberg L et al. Scandinavian Clinical Practice Guidelines on the diagnosis, management and follow-up of anaphylaxis during anaesthesia. Acta Anaesthesiol Scand, 2007; 51:655670.

11. Dewachter P, Mouton-Faivre C, Emala CW. Anaphylaxis and anesthesia: controversies and new insights. Anesthesiology, 2009; 111:11411150.

12. Soar J, Deakin C, Nolan J et al. European Resuscitation Council guidelines for resuscitation 2005. Section 7. Cardiac arrest in special circumstances. Resuscitation, 2005; 67:S135-S170.

13. Brown SGA, Blackman KE, Stenlake $V$ et al. Insect sting anaphylaxis; prospective evaluation of treatment with intravenous adrenaline and volume resuscitation. Emerg Med J, 2004, 2004; 21:149-154.

14. Holt NF, Haspel KL. Vasopressin: a review of therapeutic applications. $J$ Cardiothorac Vasc Anesth, 2010; 24:330-347.

15. Soar J, Perkins GD, Abbas G et al. European Resuscitation Council Guidelines for Resuscitation 2010. Section 8. Cardiac arrest in special circumstances: Electrolyte abnormalities, poisoning, drowning, accidental hypothermia, hyperthermia, asthma, anaphylaxis, cardiac surgery, trauma, pregnancy, electrocution. Resuscitation, 2010; 81:1400-1433.

16. Harper NJ, Dixon T, Dugue $P$ et al. Suspected anaphylactic reactions associated with anaesthesia. Anaesthesia, 2009; 64:199-211.

17. Mertes PM, Lambert M, Guéant-Rodriguez RM et al. Perioperative anaphylaxis. Immunol Allergy Clin North Am, 2009; 29:429-451.

18. Filon FL, Radman G. Latex allergy: a follow up study of 1040 healthcare workers. Occup Environ Med, 2006; 63:121-125.

19. Katz JD, Holzman RS, Brown RH et al. Natural rubber latex allergy. Considerations for anesthesiologists. New York, American Society of Anesthesiologists, 2005. Disponível em: <http://ecommerce.asahq. org/publicationsAndServices/latexallergy.pdf $>$

20. Hallgren J, Pejler G. Biology of mast cell tryptase. An inflammatory mediators. FEBS J, 2006; 273:1871-1895.

21. Fisher MM, Baldo BA. Mast cell tryptase in anaesthetic anaphylactoid reactions. Br J Anaesth, 1998; 80:26-29.

22. Shaffer HC, Parsons DJ, Peden DB et al. Recurrent syncope and anaphylaxis as presentation of systemic mastocytosis in a pediatric patient: case report and literature review. J Am Acad Dermatol, 2006; 54:S210-S213.

23. Guttormsen $A B$, Johansson $\mathrm{SGO}$, Öman $\mathrm{H}$ et al. No consumption of $\lg \mathrm{E}$ antibody in serum during allergic drug anaphylaxis. Allergy, 2007; 62:1326-1330

24. Garvey LH, Kroigaard M, Polsen LK et al. IgE-mediated allergy to chlorhexidine. J Allergy Clin Immunol, 2007; 120:409-415.

Resumen: Machado JA, Cunha RC, Oliveira BH, Silva J - Reacción Anafiláctica Inducida por el Látex en Paciente Sometido a la Apendicectomía Abierta. Relato de Caso.

Justificativa y objetivos: Aunque exista un aumento en la incidencia de alergia al látex en la población en general, los eventos graves de anafilaxia durante algunos procedimientos quirúrgicos por suerte todavía son raros, aunque con un nivel de morbilidad y mortalidad elevados. La prevención, el diagnóstico, el rápido tratamiento y el seguimiento de los pacientes afectados por ese evento, representan un reto para el anestesiólogo. El presente relato intentó describir un caso de anafilaxia grave al látex y discutir su diagnóstico y tratamiento.

Relato del caso: Paciente del sexo femenino, 39 anos, blanca y con sospecha diagnóstica de apendicitis, que fue derivada a quirófano para un procedimiento urgente bajo raquianestesia. Aproximadamente 30 minutos después del inicio de la cirugía, presentó un cuadro de anafilaxia con parada cardiorrespiratoria, revertida posteriormente al tratamiento. Uno de los cuidados tomados fue el aislamiento de eventuales agentes causales, siendo que, posteriormente, la paciente fue derivada a la Unidad de Cuidados Intensivos y evolucionó sin secuelas. La dosificación de IgE-RAST (Radioallergosorbent Test), específico para el látex fue positiva. La paciente fue derivada para seguimiento con el alergista.

Conclusiones: El anestesiólogo debe concentrar sus esfuerzos en la anamnesis, aunque en los procedimientos de urgencia, sea consciente de las limitaciones que se presentan en esas ocasiones. El pronóstico de anafilaxia depende del rápido inicio del tratamiento adecuado, y el diagnóstico no se restringe al momento del evento, sino a la determinación del factor causal. Crear un medio de seguimiento para esos pacientes, como lo hacen otros centros internacionales, parece ser el camino que debe ser secundado.

Descriptores: ANESTESIA: Regional, raquianestesia; CIRUGÍA: Abdominal; COMPLICACIONES, Alergia, Parada cardiorespiratoria. 